\title{
Online Casino Advertising: Testing the Limits of CoMmercial Speech
}

\author{
Andrew Hall ${ }^{1}$ \\ Spring 2006 \\ Copyright (C) University of Pittsburgh School of Law \\ Journal of Technology Law and Policy
}

\section{Introduction}

The advent of the Internet has revolutionized the daily lives of everyone by giving increased access to information and consumer transactions, while also adding change and further complexity to the law. Gambling has adapted to the arrival of the Internet with online sports books ${ }^{2}$ and online casino gambling, ${ }^{3}$ both developing a presence on the Internet. These new online casinos have begun to advertise both on the Internet and through more traditional broadcasting, like radio and television. ${ }^{4}$ As a result, the Department of Justice has begun to crack down on online casino advertisers, primarily by

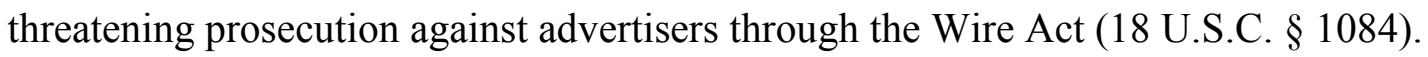
One of these advertisers is Casinocity.com, a for-profit Louisiana corporation that runs a website that disseminates information about online casinos, casino-style games, and sports betting. ${ }^{5}$ In June 2003, the Department of Justice sent a memo to the National Association of Broadcasters warning that those who advertised for online casinos could

\footnotetext{
${ }^{1}$ University of Pittsburgh School of Law, J.D. expected 2006.

${ }^{2}$ See Sportsbook.com, at http://www.sportsbook.com (last visited Jan. 29, 2005) (sports books allow gamblers to place bets on the outcome of various outcomes of a sporting event like the final score of the game or the total points scored in the game).

${ }^{3}$ See Goldenpalace.com, at http://www.goldenpalace.com (last visited Jan. 29, 2005) (online casinos allow bettors to play traditional casino games like blackjack and roulette).

${ }^{4}$ See Brent Jex, Online Casinos: A New Area for Presentation, 2002 UCLA J. L. \& TECH. Notes 8 (2002)

(noting that online casinos are the fifth largest industry advertiser in the United States).

${ }^{5}$ See Casinocity.com, at http://www.casinocity.com (last visited Jan. 29, 2005).
} 
face felony prosecutions with possible imprisonment and heavy fines if advertisers continued airing online casino advertisements. ${ }^{6}$ Casinocity.com believes that the threats of the Department of Justice violate the free speech rights of the advertisers and has left many advertisers fearful of continuing to advertise their casinos. ${ }^{7}$ Casinocity.com also argues that the reduction in advertisements has economically hampered those who rely on advertising revenues from online casinos. ${ }^{8}$ The website filed suit against the Department of Justice in 2004 and sought a declaratory judgment that regulation of online casino advertisements violates Casinocity.com's First Amendment rights. ${ }^{9}$ In addition, the website also sought an injunction to prevent the Department of Justice from prosecuting Casinocity.com for advertising online casinos. ${ }^{10}$ After an adverse ruling in the U.S. District Court for the Middle District of Louisiana, the case is pending in the United States Court of Appeals for the Fifth Circuit.

Casinocity.com and betonsports.com have begun a public awareness campaign to increase support for online casino advertising, but despite these efforts, some online casino advertisers have settled with the government to prevent future prosecution for

\footnotetext{
${ }^{6}$ See Complaint for Plaintiff at 2, Casino City, Inc. v. United States Dep't of Justice, No. 04-557-B-M3, (M.D.La. filed Aug. 9, 2004), available at http://online.casinocity.com/FirstAmendment/action.cfm (last visited Jan. 29, 2005).

${ }^{7}$ See Complaint for Plaintiff at 2, Casino City, Inc. v. United States Dep't of Justice, No. 04-557-B-M3, (M.D.La. filed Aug. 9, 2004), available at http://online.casinocity.com/FirstAmendment/action.cfm (last visited Jan. 29, 2005); See also Lorraine Wollert, Can Online Betting Change Its Luck, BusINESS WeEK, Dec. 20, 2004, available at http://www.businessweek.com/magazine/content/04_51/b3913097.htm (last visited Feb. 7, 2005).

${ }^{8}$ Complaint for Plaintiff at 3, Casino City, Inc. v. United States Dep't of Justice, No. 04-557-B-M3, (M.D.La. filed Aug. 9, 2004), available at http://online.casinocity.com/FirstAmendment/action.cfm (last visited Feb. 7, 2005).

${ }^{9}$ See Online Casino City, Casino City Files Suit Against U.S. Department of Justice to Establish its First Amendment Right to Advertise Online Casinos and Sportsbooks, OnLINE CASINO CiTY, August 9, 2004, available at http://online.casinocity.com/firstamendment/ (last visited March 7, 2006).

${ }^{10} I d$.
} 
advertising for online casinos. ${ }^{11}$ Recently, three St. Louis area radio stations paid the Department of Justice $\$ 158,000$ to avoid further prosecution for its online casino advertising. ${ }^{12}$ As part of their settlement, the radio stations also admitted that their activities were illegal, adding further spark to the debate about the legality of online casino advertising. ${ }^{13}$

Despite the recent admission of the three St. Louis radio stations and the U.S. District Court ruling, the legality of online casino advertising is still a largely unsettled issue. In deciding the issue, courts will have to apply current case law regarding casino advertising to an online casino context. This means that the Supreme Court's Central Hudson test for commercial speech regulation will guide the court's analysis in this case, with its analysis hinging on whether or not online gambling is found to be legal. A court will also have to solve jurisdictional issues, as laws on the legality of gambling are different throughout the United States. All the potential solutions to this issue have pitfalls. A court will have to decide on an alternative that is reasonable and respects jurisdictional and federalism concerns. Ultimately, the court should find that there is no effective way to control online gambling and no major benefit to prohibiting online casino advertisements.

In order to completely understand the issue presented to the court, Section II of this paper will discuss the development of commercial speech law, and Section III will show modern application of the Central Hudson test to casino advertising. Section IV

\footnotetext{
${ }^{11}$ Betonsports.com Joins Free Speech Fight, Casinocity.com, Sep. 8, 2004, available at http://www.onlinecasinonews.com/ocnv2_1/article/article.asp?id=6293 (last visited Nov. 12, 2004).

${ }^{12}$ U.S. Radio Stations pay up for advertising iGaming Site, Casinocity.com, Sept. 29, 2004, available at http://www.onlinecasinonews.com/ocnv2_1/article/article.asp?id=6458 (last visited Nov. 12, 2004).

${ }^{13}$ U.S. Radio Stations pay up for advertising iGaming Site, Casinocity.com, Sept. 29, 2004, available at http://www.onlinecasinonews.com/ocnv2_1/article/article.asp?id=6458 (last visited Nov. 12, 2004).
} 
discusses laws that can be applied to online casino advertising, while Section V applies the Central Hudson test to an online casino advertising circumstance. Section VI discusses the U.S. District Court's February 2005 ruling, while Section VII discusses likely outcomes to Casinocity.com's litigation. Finally, Section VII offers my opinion on what should be the result of the case.

\section{The Development of Commercial Speech Law}

\section{A. Virginia State Board of Pharmacy v. Virginia Citizens Consumer Council}

Commercial speech law began its development with the 1977 case, Virginia State Board of Pharmacy v. Virginia Citizens Consumer Council, where the Supreme Court held that commercial speech was a right protected by the First Amendment of the United States Constitution. ${ }^{14}$ While the Court recognized the right to commercial speech, it also held that commercial speech was not an absolute right and could be regulated. ${ }^{15}$ In their decision, the Supreme Court had to balance the protections provided by the First Amendment and the government's right to regulate commerce, opining, "[i]n concluding that commercial speech, like other varieties, is protected, we of course do not hold that it can never be regulated in any way. Some forms of commercial speech regulation are surely permissible." ${ }^{16}$ The Court reasoned that commercial speech was protected because the speech was not so removed from any "exposition of ideas," ... and from "truth, science, morality, and arts in general ... that it lacks all protection ...."17 The decision in Virginia State Board of Pharmacy laid the framework for the Supreme Court's Central

\footnotetext{
${ }^{14}$ Va. State Bd. of Pharm. v. Va. Citizens Consumer Council, 425 U.S. 748, 770 (1976).

${ }_{16}^{15} \mathrm{Id}$.

${ }^{16}$ Id. at 770 .

${ }^{17}$ Id. at 762 .
} 
Hudson decision that established the current test for the permissibility of government regulation of commercial speech.

B. Central Hudson Gas \& Electric Corp. v. Public Service Commission of New York In Central Hudson, the Supreme Court expanded upon the groundwork it recognized in the Virginia State Board of Pharmacy case by establishing a four prong test to assess the constitutionality of government regulation of commercial speech. In 1973, the Public Service Commission of New York banned all advertising for commercial utilities because the New York state utility commission did not have adequate fuel supplies to furnish all customer demands for the upcoming winter. ${ }^{18}$ After the state's energy shortage subsided three years later, the Public Service Commission assessed whether or not to continue their advertising ban. ${ }^{19}$ The Public Service Commission divided utility advertising into two groups - promotional advertising and informational advertising. ${ }^{20}$ Promotional advertising was advertising that encouraged people to use a utility, while informational advertising was more of a public service message - such as encouraging consumers to use electricity during non-peak usage hours. After deliberation, the Public Service Commission extended the ban only on promotional advertising because the Commission believed that allowing promotional advertising did not advance their interest in energy conservation. ${ }^{21}$ Central Hudson then filed suit, arguing that the ban on promotional advertising violated the First and Fourteenth Amendments.

\footnotetext{
${ }^{18}$ Cent. Hudson Gas \& Elec. Corp. v. Pub. Serv. Comm'n, 447 U.S. 557, 558-59 (1980).

${ }^{19} I d$. at 559 .

${ }^{20} I d$. at $559-60$.

${ }^{21} I d$.
} 
The Supreme Court reaffirmed their position from Virginia State Board of Pharmacy, noting that commercial speech had some First Amendment protection but could still be regulated. The Court then laid out a four part test for commercial speech regulation. The first prong of the Central Hudson test allows regulation of speech that is more likely than not to deceive the public and to speech that concerns illegal activity. ${ }^{22}$ If the speech is neither deceptive nor illegal, then the government's ability to regulate commercial speech is greatly limited. Second, the government must have a substantial government interest in regulating the commercial speech. ${ }^{23}$ Third, the government's interest must be directly advanced by the proposed regulation on speech. ${ }^{24}$ Finally, if the first three criteria are met, the government regulation must be the least restrictive way to advance the substantial government interest. ${ }^{25}$

In applying the new test, the Supreme Court ruled that the Public Service Commission's regulation violated Central Hudson's right to commercial speech. ${ }^{26}$ The Court found that the first prong of the test was not at issue, as both parties acknowledged the advertising was lawful and not misleading. ${ }^{27}$ Second, the Court affirmed the Public Service Commission's two substantial government interests. The Court agreed that the Commission had a substantial interest in discouraging further energy consumption and in preventing more peak usage of utilities that would result in higher rates for utilities consumers. ${ }^{28}$ Third, the Court concluded that the regulation directly advanced the Commission's interest in energy conservation. However, the Court did not believe that

\footnotetext{
${ }^{22} I d$. at 564.

${ }^{23}$ Cent. Hudson Gas \& Elec. Corp, 447 U.S. at 564.

${ }^{24} \mathrm{Id}$.

${ }^{25} I d$.

${ }^{26} I d$. at 572 .

${ }^{27} I d$. at 566 .

${ }^{28} I d$. at 568.
} 
the Public Service Commission's regulation was the least restrictive means to advance its government interest because the Commission could not prove that an individual's energy consumption was directly linked to promotional advertising. ${ }^{29}$ In fact, the Court stated that promotional advertising might increase energy conservation because it would allow utilities to advertise energy-saving devices. ${ }^{30}$ Alternatively, the Court noted that the government interests could be more effectively advanced by regulating the type and content of promotional advertising rather than banning all types of commercial advertising. ${ }^{31}$ These apparent gaps in the Public Service Commission's rule led the Supreme Court to overturn the regulation against promotional advertising of utilities.

III. Modern application of the Central Hudson Test

\section{A. Greater New Orleans Broadcast Ass'n v. United States}

In 1999, the Supreme Court issued its most recent decision regarding casino advertising in Greater New Orleans Broadcast Ass' $n$ v. United States. The plaintiff, Greater New Orleans Broadcasting Association, was a conglomerate of radio and television broadcasters in the New Orleans area. ${ }^{32}$ These broadcasters wanted to broadcast advertisements for legal, for-profit, private casinos located in Louisiana and Mississippi. ${ }^{33}$ However, the broadcasters did not run these advertisements for fear of violating 18 U.S.C. $\S 1304$, which prohibits broadcasters from running advertisements for private casinos. The broadcasters sought a judgment that would declare 18 U.S.C. $\S 1304$ unconstitutional for violating their First Amendment rights. In addition, the broadcasters asked for an injunction that would prohibit future government prosecution for violating

\footnotetext{
${ }^{29} I d$. at 569.

${ }^{30} \mathrm{Id}$. at 570 .

${ }^{31}$ Cent. Hudson Gas \& Elec. Corp, 447 U.S. at 571.

${ }^{32}$ Greater New Orleans Broad. Ass'n. v. United States, 527 U.S. 173, 180 (1999).

${ }^{33} I d$. at $180-81$.
} 
this act. ${ }^{34}$ In deciding the case, the Supreme Court used the four-prong Central Hudson test but also focused on the evolution of federal statutes regarding casino advertising.

In its analysis, the Supreme Court focused on the evolution of federal casino advertising statutes, noting that several statutes had recently been enacted that allowed for some casino advertising. The first major loophole occurred in the 1970s, when the federal government carved out an exception to allow advertising for state-run lotteries. ${ }^{35}$ Second, in 1988, Congress passed a law allowing for Indian tribes to build and run private casinos. This regulation also gave broadcasters permission to advertise for tribalbased casinos. ${ }^{36}$ Finally, the Charity Games Advertising Clarification Act, which was also passed in 1988, allowed advertising for any lottery, game, or similar scheme if conducted by “(i) any governmental organization; (ii) any not-for-profit organization; or (iii) a commercial organization as a promotional activity clearly occasional and ancillary to the primary business of that organization. ${ }^{, 37}$ The primary purpose behind the Court's analysis of these recent federal regulations was to show a trend towards greater acceptance of gambling as a legal and legitimate activity. Further, most of these regulations showed a more relaxed opinion towards gambling and suggested that 18 U.S.C. $\S 1304$ was no longer an effective regulation.

In addition to the above statutory analysis, the Supreme Court used the Central Hudson test to determine the permissibility of commercial speech regulation. As was the case in Central Hudson, the first prong of the test, a legal and non-misleading activity,

\footnotetext{
${ }^{34} I d$. at 181.

${ }^{35}$ Greater New Orleans Broad. Ass'n, 527 U.S. at 178.

${ }^{36} \mathrm{Id}$. at $178-79$.

${ }^{37}$ Id. at 179 .
} 
was not in dispute. ${ }^{38}$ The advertising in question was legal because the advertisements were to be broadcast in Louisiana, where casino gambling is legal. The Court accepted with reservation the two substantial government interests that were given. The government argued that a ban on casino advertising would advance the substantial governmental interests of "(1) reducing the social costs associated with 'gambling' or 'casino gambling,' and (2) assisting States that 'restrict gambling' or 'prohibit casino gambling' within their own borders. ${ }^{, 39}$ In supporting the government interests asserted, the Court noted "the social costs that support the suppression of gambling are offset, and sometimes outweighed, by countervailing policy considerations, primarily in the form of economic benefits" gained by gambling. ${ }^{40}$ Nonetheless, the Court expressed its greatest concerns about a prohibition on casino advertising in the final two prongs of the Central Hudson test.

The government argued their regulation advanced substantial government interests because prohibiting casino advertising would lessen the demand for gambling. ${ }^{41}$ The government also argued their regulation prevented the detrimental effects persuasive advertising could have on compulsive gamblers. ${ }^{42}$ Finally, the government asserted that their restriction helped protect bordering states that prohibit gambling from facing the negative social and economic effects that result from broadcasts of casino advertising. ${ }^{43}$

The Supreme Court did not accept the government's rationales, believing that promotional advertising for casinos would likely channel gamblers to a specific casino

\footnotetext{
${ }^{38} I d$. at 184.

${ }^{39}$ Greater New Orleans Broad. Ass'n, 527 U.S. at 185.

${ }^{40}$ Id. at 186.

${ }^{41} I d$. at 188-89.

${ }^{42} I d$.

${ }^{43} I d$. at 194.
} 
and not greatly increase the number of total gamblers. ${ }^{44}$ The Court also found that any measure of the effectiveness of the Government's attempt to minimize the social costs of gambling is undermined by the federal government's encouragement of tribal casino gambling. The federal government's encouragement of tribal casino gambling meant that states that prohibited gambling would not be helped by a regulation that only prohibited certain types of casino advertising. ${ }^{45}$ The Court elaborated that the government is committed to "prohibiting accurate product information, not commercial enticements of all kinds, and then only when conveyed over certain forms of media and for certain types of gambling ... despite the fact that messages about the availability of such gambling are being conveyed over the airwaves ...."46 Though the Court prohibited regulation of casino advertising in Greater New Orleans Broadcast Ass'n, other cases have upheld regulation of casino advertising. ${ }^{47}$

\section{B. United States v. Edge Broadcasting Co.}

While Greater New Orleans Broadcast Association established that casino advertising was permissible in states that allowed casino advertising, Edge Broadcasting Co. affirmed the right of non-gambling states to prohibit lottery-related advertising within their respective borders. ${ }^{48}$ This 1993 Supreme Court case dealt with whether or not lottery advertising from a state that did not permit the lottery was permissible if part of the broadcaster's intended audience lived in a state that did allow for a lottery. ${ }^{49}$ Edge Broadcasting owned a radio station licensed in Elizabeth City, North Carolina, which was

\footnotetext{
${ }^{44} I d$.

${ }^{45} I d$.

${ }^{46}$ Greater New Orleans Broad. Ass'n, 527 U.S. at 191.

${ }^{47} I d$. at 195.

${ }^{48}$ United States v. Edge Broad. Co., 509 U.S. 418 (1993).

${ }^{49}$ Id. at 423.
} 
three miles from the North Carolina and Virginia borders. ${ }^{50}$ The station's goal was to reach a largely Virginian audience. Edge Broadcasting wanted to broadcast advertisements for the Virginia Lottery, but was forbidden to do so under 18 U.S.C. $\S$ 1304. However, under 18 U.S.C. $\S 1307$, an exception to the requirements of 18 U.S.C. $\S$ 1304 is given to advertisers in states that permit lotteries. ${ }^{51}$ Because North Carolina did not permit a state lottery, Edge Broadcasting sought an order in the District Court for the Eastern District of Virginia declaring that 18 U.S.C. $\S \S 1304$ and 1307 were unconstitutional. ${ }^{52}$ Additionally, Edge Broadcasting also sought an injunction against the enforcement of these regulations. ${ }^{53}$ The District Court held that the regulation did not pass the Central Hudson test because it did not directly advance a substantial government interest. ${ }^{54}$ The Court of Appeals for the Fourth Circuit affirmed this decision. ${ }^{55}$

The Supreme Court quickly affirmed the first two prongs of the Central Hudson test noting that if advertisements were permitted they would concern a lawful and nonmisleading activity (the lottery is a legal activity in Virginia). ${ }^{56}$ In addition, the Court also affirmed the stated government interests of protecting the rights of states that do not allow the lottery and not interfering in the advertising of those states that do allow for state lotteries. ${ }^{57}$ The more contentious issue for the Court of Appeals for the Fourth Circuit and the Supreme Court was whether or not the government interest was directly advanced by the regulation promulgated by the state. Ultimately, the Supreme Court held

\footnotetext{
${ }^{50} I d$.

${ }^{51} I d$.

${ }^{52}$ Edge Broad. Co., 509 U.S at 424.

${ }^{53} \mathrm{Id}$.

${ }_{55}^{54}$ d. at $424-25$.

${ }^{55} \mathrm{Id}$.

${ }^{56} \mathrm{Id}$. at 426 .

${ }^{57} I d$.
} 
that a substantial government interest was advanced by the regulation. ${ }^{58}$ The Supreme Court believed the regulation advanced a government interest because it protected the rights of those states that did not have a state lottery, but did not restrict the rights of those states that wanted to advertise a lottery. ${ }^{59}$ The Court noted it was impossible to completely suppress lottery advertising in those states that forbid the lottery, so this was the best compromise available to all states. ${ }^{60}$ The Court also found that the regulation was narrowly tailored as required by the fourth prong of the Central Hudson test because the restriction was the only way to protect North Carolina's interest in preventing lottery advertisements. ${ }^{61}$ Edge Broadcasting leaves a rule that proves to be confusing for online casino cases: gambling-related advertising is permissible in states that allow for gambling, but may be prohibited in states that prohibit advertising. Applying these Court decisions to online casino advertising will prove to be troublesome because of the undefined jurisdictional bounds of the Internet.

\section{Valley Broadcasting Co. v. United States}

A 1997 decision of the Court of Appeals for the Ninth Circuit helps to define the rule given in Edge Broadcasting. Valley Broadcasting ran two Nevada television stations that broadcasted primarily in Nevada. ${ }^{62}$ Valley Broadcasting wanted to run advertisements for local casinos in Nevada, where gambling was legal. ${ }^{63}$ However, in addition to its Nevada audience, Valley Broadcasting's signal reached audiences in Utah

\footnotetext{
${ }^{58} I d$. at $428-29$.

${ }^{59} \mathrm{Id}$.

${ }^{60} I d$.

${ }^{61}$ Edge Broad. Co., 509 U.S at 429.

${ }^{62}$ Valley Broad. Co v. United States., 107 F.3d 1328, 1330 (9th Cir. 1997).

${ }^{63} \mathrm{Id}$.
} 
and California. ${ }^{64}$ Valley Broadcasting sought an injunction from the court against 18 U.S.C. $\S 1304$ so that it could advertise for these Nevada-based private casinos. ${ }^{65}$ In its analysis, the Court of Appeals for the Ninth Circuit affirmed the first two prongs of the Central Hudson test stating that the advertisements would be legal and nonmisleading. The Court of Appeals for the Ninth Circuit also recognized the government's interests in reducing public attention to gambling and protecting the interests of those states that do not permit casino gambling within their borders. ${ }^{66}$ The Court found that 18 U.S.C. $§ 1304$ did not pass the Central Hudson test because it did not directly advance the government interest. The Court noted concerns about exceptions to 18 U.S.C. $\S 1304$ that limit the effectiveness of a ban on casino advertising. ${ }^{67}$ Specifically, the court mentioned exceptions granted to state-run lotteries, fishing contests, not-for-profit lotteries, promotional lotteries and tribal-run casinos. ${ }^{68}$ The court believed that these exceptions were substantial enough to make the advancement of the government interest ineffective. ${ }^{69}$ Valley Broadcasting indicates that the site of the advertising determines the legality of the advertising. As a result, broadcasters located in a state that permits gambling are allowed to run advertisements for private casinos regardless of whether or not those advertisements reach states that do not permit gambling. On the other hand, broadcasters in states that do not permit gambling are not allowed to advertise for private casinos even if a majority of the broadcaster's audience is in a state that permits gambling.

\footnotetext{
${ }^{64} I d$.

${ }^{65} \mathrm{Id}$.

${ }^{66}$ Valley Broad. Co., 107 F.3d at 1330-31.

${ }^{67}$ Id. at 1334 .

${ }^{68} \mathrm{Id}$. at 1334 .

${ }^{69} \mathrm{Id}$.
} 


\section{Federal Statutes That Could Be Applied To Online Casinos}

\section{A.18 U.S.C. $\$ 1084:$ The Wire Act}

The federal government has referenced the Wire Act, 18 U.S.C. $\S 1084$, as its likely avenue for prosecuting those who advertise for online casinos. The act makes it illegal to transmit or to help transmit over wire communication bets or wagers on sporting events, money that would assist in placing a bet, or any information that would assist in placing a bet or wager on a sporting event. ${ }^{70}$ The Act provides a safe-harbor exemption if the transaction is between two locations where gambling is legal. ${ }^{71}$ The policy of the federal government is that advertising for these online casinos is equivalent to providing information that would assist in placing an illegal wager. However, it is important to note that many commentators believe that traditional casino gambling is not covered by the Wire Act. ${ }^{72}$

The application of the Wire Act to online casino advertising has a few problems. First, some observers have doubts as to whether the Internet should be considered a wire communication. Certainly the Internet was not a wire communication as envisioned by Congress when it promulgated this act in 1961. A recent article suggests that Congress should amend the Wire Act to ensure that Internet transactions fall under wire communications as defined by the Act. ${ }^{73}$ Second, the Wire Act only deals with sports bets and wagers. Online casinos that only have traditional casino games, like blackjack and roulette, would not fall under the scope of the Wire Act even if the act were amended

\footnotetext{
${ }^{70}$ Wire Act, 18 U.S.C. $\S 1084$ (a) (2004).

${ }^{71}$ Id. $\S 1084(\mathrm{~b})$.

${ }^{72}$ Lawrence Walters, Advertising Online Casinos: An analysis of legal rights and risks, 7 GAMING L. REV. 111, 116 (2003) (illustrates potential problems with the Wire Act).

${ }^{73}$ No Ads for Foreign Casinos, CHRISTIAn SCIENCE MONITOR, Sept. 3, 2004, available at http://www.csmonitor.com/2004/0903/p08s01-comv.html (last visited Nov. 2, 2004).
} 
to include Internet transactions. While the Wire Act likely has some application to the regulation of online casino advertising, the federal government would run into problems if it tried to apply the act to all online casino gambling as the Act is currently promulgated.

\section{B. 18 U.S.C. $\oint \oint 1304$ and 1307: Broadcasting Lottery Information}

18 U.S.C. $§ 1304$, which deals with gambling advertising, is another statute that could be applied against those who allow online casino advertising. The provision makes it illegal for any radio or television station to knowingly broadcast any advertisement or information related to any lottery, gift enterprise or similar scheme or to offer prizes based on a lottery or similar scheme. ${ }^{74}$ Though 18 U.S.C. $\S 1304$ does not specifically reference private casino gambling, the regulation was nevertheless used to prosecute the broadcasters in Greater New Orleans Broadcasting Association v. United States and could be applied to radio or television stations that advertise for online casinos. A separate statute, 18 U.S.C. $\S 1307$, provides an exception to 18 U.S.C. $\S 1304$ in states that permit a lottery, gift enterprise, or similar scheme. 18 U.S.C. $\S 1304$ and $\S 1307$ are consistent with the decision of the Supreme Court in Greater New Orleans Broadcasting Association v. United States because both allow for private casino advertising in states that permit gambling and forbid advertising in states that prohibit gambling.

V. Application of the Central Hudson test to online casino advertising

As was discussed in Section III, because the advertising would be classified as commercial speech, a court would use the Central Hudson test as its mode of analysis to evaluate the legality of online casino advertising. While it is impossible to predict with certainty how the courts would apply the test, a court would have to examine previous

${ }^{74} 18$ U.S.C. $\S 1304$ (2004). 
case law regarding traditional casino advertising to decide the legality of online casino advertising. Under this assumption, a court's analysis would be based on current case law indicating that casino advertising is permissible in those states that allow for gambling, while such advertising would be illegal in those states that do not allow gambling. However, a more detailed look at the Central Hudson test is necessary to predict the legal standing of online casino advertising.

\section{A. Substantial Government Interest}

The second prong of the Central Hudson test requires the government to have a substantial government interest in regulating the proposed commercial speech. ${ }^{75}$ The government has generally given two interests in regulating traditional casino advertising. First, the government has argued that a regulation on casino advertising discourages people from gambling, which in turn decreases the negative economic and social costs that can result from compulsive gambling. ${ }^{76}$ Second, the government has argued that a restriction on casino advertising protects the interests of those states that do not permit gambling. ${ }^{77}$ Courts have, without much debate, historically affirmed these two interests as substantial government interests. ${ }^{78}$ Only in Greater New Orleans Broadcasting Association did the Supreme Court express reservation with the government interests,

\footnotetext{
${ }^{75}$ Cent. Hudson Gas \& Elec. Corp., 447 U.S. at 564.

${ }^{76}$ Greater New Orleans Broad. Ass'n, 527 U.S. at 185.

${ }^{77} \mathrm{Id}$.

${ }^{78}$ Id.; See also Edge Broad. Co., 509 U.S. at 426; Valley Broad. Co., 107 F.3d at 1330-31.
} 
noting that the social and economic losses that result from compulsive gambling might be offset by other economic gains that result from gambling. ${ }^{79}$

Applying these substantial government interests to online casino advertising would lead to results similar to previous case law. The government would still be concerned with the negative social and economic effects of gambling. ${ }^{80}$ Online casinos provide increased access to potential gamblers so the government could argue that compulsive gambling may be even more detrimental to those users who are only a click away from gambling. ${ }^{81}$ Second, the government would still have a responsibility to protect the interests of those states that prohibit gambling. ${ }^{82}$ Allowing unrestricted advertising in states where gambling is illegal infringes on a state's autonomy to regulate issues within its borders. However, advertisers would not be able to confine their advertisements to only those states that permit gambling. This dilemma leads to a series of jurisdictional questions that will be discussed in further detail later in this note.

In addition to the previously asserted interests, the government also has an interest in protecting consumers from potentially "crooked" online casino games. ${ }^{83}$ Gambling online is a risky proposition because there is no way to guarantee the authenticity of a game. For example, in a traditional casino game of roulette, a gambler can be guaranteed that if the ball landed on a certain number, the result was legitimate. With traditional casinos, state gambling regulators have the ability to ensure that casinos in their state are

\footnotetext{
${ }^{79}$ Greater New Orleans Broad. Ass'n, 527 U.S. at 186.

${ }^{80}$ See Theresa Loscalzo \& Stephen Shapiro, Internet Gambling Policy: Prohibition versus Regulation, 7 VILL. SPORTS \& ENT. L.J. 11 (2000) (describes the potential new social and economic risks associated with online gambling).

${ }^{81}$ See Theresa Loscalzo \& Stephen Shapiro, Internet Gambling Policy: Prohibition versus Regulation, 7 VILL. SPORTS \& ENT. L.J. 11 (2000)

${ }^{82}$ See supra $\S$ III-B.

${ }^{83}$ See Loscalzo \& Shapiro, Internet Gambling Policy: Prohibition versus Regulation, 7 VILL. SPORTS \& ENT. L.J. 11 (2000).
} 
fair and honest. ${ }^{84}$ However, there is no such guarantee in an online casino. A website could program its online casinos to never allow a gambler to win or for the gambler to win a smaller percentage of games than he or she would statistically win in a traditional casino. Because these casinos are often outside of a state's jurisdiction, states would not be able to effectively regulate gambling like they can with traditional casinos.

\section{B. Advancement of the Substantial Government Interests}

Advancement of a substantial interest has been more troublesome for the government to prove than the existence of the substantial interest. Several recent decisions have held that the government had not substantially advanced its interests because legislative exceptions to the ban on casino advertising make other attempts to ban casino advertising ineffective. Greater New Orleans Broadcasting Association catalogued the several legislative exceptions that made the regulation ineffective. Included in the court's analysis were exceptions granted to state-run lotteries, to tribalowned private casinos, and to lotteries or similar schemes if run by state governments, charitable organizations, or those ancillary to a company's business. ${ }^{85}$ Courts have also said that the government's interest in preventing the negative effects of gambling are not helped by a ban on advertising because casino advertising does not encourage someone to gamble, but rather encourages someone to gamble at a particular casino. ${ }^{86}$ As a result, the growing trend in traditional casino advertising analysis is not to affirm the government's advancement of the substantial government interest.

\footnotetext{
${ }^{84}$ See Nevada Gaming Commission, at http://gaming.nv.gov/ (last visited Jan. 26, 2005).

${ }^{85}$ See supra § III-A.

${ }^{86}$ Greater New Orleans Broad. Ass'n, 527 U.S. at 194.
} 
When applying this second prong to an online casino advertising situation, the courts will reach results similar to those in other recent casino advertising cases. A court would most likely decide that the legislative exceptions that have invalidated regulations in cases like Greater New Orleans Broad. Association would invalidate an attempted ban on online casino advertising. ${ }^{87}$ While online gambling may be somewhat different from traditional casino gambling, the negative social and economic effects of gambling are the same. ${ }^{88}$ Even though exceptions cited in previous cases do not concern online gambling, a court should find that these exceptions weaken an argument for regulating online casino advertising. However, these exceptions may not be enough to invalidate a regulation on online casino advertising. For instance, a court may find that the negative effect of online gambling is greater than traditional gambling and may want to discourage online gambling at all costs. In this scenario, the court would uphold the advancement of the government's interest despite the exceptions cited by the Supreme Court in its recent decisions. In effect, the court may find the potential harm of online gambling greater than any flaws in the government's argument.

When examining the advancement of a substantial government interest, the courts should realize that a ban on online casino advertising cannot be entirely effective. Since the Internet does not conform to traditional notions of borders and jurisdictions, enforcing a ban on online casino advertising becomes difficult. ${ }^{89}$ Even assuming a one-hundred percent effective ban on online casino advertising in the United States, the government

\footnotetext{
${ }^{87}$ See supra $\S$ III-A.

${ }^{88}$ See Loscalzo \& Shapiro, Internet Gambling Policy: Prohibition versus Regulation, 7 VILL. SPORTS \& ENT. L.J. 11 (2000).

${ }^{89}$ See Jack Goldsmith, The Internet and the Abiding Significance of Territorial Sovereignty, 5 IND. J. GLOBAL LEGAL. STUD. 475 (1998) (advances idea that the internet challenges traditional conceptions of jurisdiction).
} 
would not be able to guarantee that United States citizens would never see advertisements for foreign online casinos. ${ }^{90}$ The federal government would have little recourse to prosecute advertisers from other countries who advertise online casinos on their websites. ${ }^{91}$ Therefore, courts will have several countervailing considerations to weigh when deciding whether or not a ban on online casino advertising is effective enough to allow the government regulation to stand.

\section{Narrowly Tailored Regulation}

Even if a court finds a substantial government interest that is advanced by the regulation against online casino advertising, the regulation will fail if it is not the least restrictive means available to advance the substantial government interest. The narrowly tailored prong of the Central Hudson test requires that a government regulation be the least restrictive method of advancing the government interest. ${ }^{92}$ For example, a regulation making all televisions illegal in order to prevent televised gambling advertisements would not be the least restrictive way of advancing an interest in preventing gambling advertisements. Recent decisions on the issue have either upheld this prong of the test without much analysis or stopped short of the prong because the regulation failed the Central Hudson test before the prong was to be analyzed.

\footnotetext{
${ }^{90}$ See Laura Bak-Boychuk, Internet Gambling: Is Avoiding Prosecution as Easy as Moving the Business Operations Offshore, 6 SW. J OF L. \& TRADE AM. 363, 383 (1999) (predicts that online gambling would be nearly impossible to effectively regulate).

${ }^{91}$ But see Bruce Keller, The Game's The Same: Why Gambling in Cyberspace Violates Federal Law, 108 YALE L.J. 1569, 1599-1603 (1999) (argues that federal law would easily reach into other countries to prosecute those who offer online gambling).

${ }_{92}$ Cent. Hudson Gas \& Elec. Corp., 447 U.S. at 564.
} 
Greater New Orleans Broadcasting Association and Valley Broadcasting did not reach this prong of the Central Hudson test because these decisions held that the respective government regulations did not directly advance the stated government interests. ${ }^{93}$ As a result, the regulations were invalidated before the court considered whether or not the regulation was narrowly tailored. ${ }^{94}$ In Edge Broadcasting, however, the Court held that the proposed government regulation was narrowly tailored because the ban on lottery advertising was the only way to effectively prevent lottery advertising in North Carolina (which did not permit a state lottery). ${ }^{95}$ This prong of the test will be considered only if a court finds that the regulation passed the first two prongs of the Central Hudson test. If a court does analyze this prong of the Central Hudson test, it will find that the government regulation is sufficiently narrowly tailored. A court would realize there is no method of enforcing an online casino advertising ban that is less intrusive. The regulation is narrowly tailored and only directly affects those who advertise for online casinos. As a result, if a court affirms the first two prongs of the test, it would likely affirm the narrowly tailored prong of the Central Hudson test.

\section{Legal and Non-misleading Activity}

For the issue at hand, the most important prong of the Central Hudson test is the legal and non-misleading activity requirement. ${ }^{96}$ Even if online casino advertising passes the other three prongs of the Central Hudson test, the regulation will be permitted if the activity to be advertised is illegal or misleading. Analysis of this requirement is difficult because the Internet creates an entirely new set of circumstances for personal jurisdiction

\footnotetext{
${ }^{93}$ Greater New Orleans Broad. Ass'n, 527 U.S. at 188; Valley Broad. Co., 107 F.3d at 1334.

94 Id.

${ }^{95}$ United States v. Edge Broad. Co., 509 U.S. at 429.

${ }^{96}$ See supra § III-A.
} 
and the site of the transaction. It is important to remember that the legal and nonmisleading requirement analyzes the legality of the activity being advertised. The few decisions that exist on the legality of online casino gambling are mixed, but generally find that online gambling is illegal. Consequently, this section analyzes the legality of online gambling and not advertising related to online gambling.

\section{i. United States v. Cohen (Prosecution under the Wire Act)}

In United States v. Cohen, the Court of Appeals for the Second Circuit upheld a conviction against Cohen and his company, World Sports Exchange, for violation of the Wire Act. ${ }^{97}$ Cohen, a United States citizen, moved to Antigua to establish an online sports book. ${ }^{98}$ He required members to register for his book and then wire at least $\$ 300$ to Antigua to open their account. When their respective accounts were opened, the members could place their wagers through the Internet or over the telephone. ${ }^{99}$ The sports book collected $\$ 5.3$ million dollars in the first fifteen months of operation and usually took a ten percent cut of each wager collected. In 1997, the Federal Bureau of Investigation began investigating the World Sports Exchange, and in 1998 arrested Cohen, charging him with eight counts, including violation of the Wire Act.

Cohen first argued that the Wire Act's safe harbor provision gave him an exemption from prosecution because gambling is legal in Antigua. ${ }^{100}$ However, the court disagreed with Cohen's argument by stating that gambling was clearly illegal in New York and that the safe harbor provision was only applicable in situations where the gambling transaction went from one state with legal gambling to another state with legal

\footnotetext{
${ }^{97}$ United States v. Cohen, 260 F.3d 68, 70 (2d Cir. 2001).

${ }^{98}$ See supra note 1 (a sports book offers sports betting where an online casino offers games seen in traditional casinos like blackjack or roulette).

${ }^{99}$ Cohen, 260 F.3d at 70.

${ }^{100}$ Id. at 73-74.
} 
gambling. ${ }^{101}$ Cohen's second argument was that his customer's wagers were placed only in Antigua; the transmission of information to Antigua was not a bet and that only when that information reached Antigua was a bet entered into a customer's account. ${ }^{102}$ The court said that the site of the actual wager was immaterial because the Wire Act prohibited the transmission of information that could lead to wagers and placing bets over the phone was clearly aiding wagers to be placed. ${ }^{103}$ United States v. Cohen shows that an online wager is an illegal activity when the Wire Act is applied. However, the Wire Act as currently written only applies to sports gambling, leaving online casinos that do not offer sports books free from application of the law. It is also important to look at personal jurisdiction to see if prosecution of traditional online gambling would be constitutional.

\section{ii. Personal Jurisdiction}

Personal jurisdiction is a crucial element for the court to decide because in states where gambling is illegal, an online casino would likely be found to be illegal if the casino could be haled into court in the jurisdiction. Millennium Enterprises $v$. Millennium Music, a 1999 Oregon District Court case, established a framework that has been used in many jurisdictional cases involving the Internet. Millennium Music was a trademark infringement case where Millennium Enterprises was trying to get an injunction against Millennium Music for using a name similar to Millennium Enterprises. ${ }^{104}$ The case hinged on whether Oregon could get personal jurisdiction over

\footnotetext{
${ }^{101} I d$.

${ }^{102} \mathrm{Id}$

${ }^{103} I d$. at $74-75$.

${ }^{104}$ Millennium Enters. v. Millennium Music, 33 F.Supp.2d 907 (D.Or. 1999).
} 
Millennium Music, a South Carolina corporation. ${ }^{105}$ Included in the jurisdictional analysis was whether Millennium Music's website gave the Court sufficient contacts in Oregon to establish jurisdiction. ${ }^{106}$ The District Court used a test established in Zippo Manufacturing Co. v. Zippo Dot Com, Inc. to analyze whether Millennium could be hailed into the Oregon Courts. The Zippo test set up a sliding scale to analyze the commercial nature of the website in question with the underlying theory being that those websites that are more commercial in nature are better able to defend themselves in courts in a foreign jurisdiction. ${ }^{107}$ The sliding scale denies jurisdiction when the website is purely informational and gives jurisdiction to websites that are commercial and transmit substantial business over the Internet. Generally, websites fall in the middle of the scale and have both commercial and informational aspects. ${ }^{108}$ This test is extremely subjective and makes it difficult to give definitive conclusions in which category a website belongs.

Though Millennium Music provides a general framework to be applied for all Internet-based jurisdiction issues, Millennium's framework has only been applied in bits and pieces in other online casino jurisdiction cases. For example, in Humphrey v.

Granite Gate Resorts, a Minnesota Appellate Court held that an online casino based in Belize that ran advertisements in Minnesota was subject to personal jurisdiction in Minnesota because it was soliciting business from citizens outside of Belize. ${ }^{109}$ Also, the United States District Court held in Inset Systems, Inc. v. Instruction Set, Inc, that

\footnotetext{
${ }^{105} I d$. at $909-10$.

${ }^{106} I d$. at 913 .

${ }^{107} \mathrm{Id}$. at 915-16.

${ }^{108}$ Millennium Enters. v. Millennium Music, 33 F.Supp.2d at 915-916.

${ }^{109}$ Humphrey v. Granite Gate Resorts, 568 N.W.2d 715 (Minn. Ct. App. 1997). Again, the issue here is the legality of the online casino, not the online casino advertising.
} 
Instruction Set, a Massachusetts corporation, was subject to personal jurisdiction in Connecticut because of the company's actions through its website. The court held that the website and a toll-free number of the company were sufficient evidence that Instruction Set intended to solicit business in Connecticut, and therefore, it was reasonable that Instruction Set anticipated being haled into court in Connecticut. ${ }^{110}$ The court further said that "substantial fair play and justice" were not violated because of the close distance between Connecticut and Massachusetts. ${ }^{111}$ This decision has received a mixed reception from other courts ${ }^{112}$ and the Connecticut court's rationale may have been different in an online casino situation where the casinos are usually located outside of the United States. Finally, in New York v. Lipsitz, a New York appellate court held that though Internet transactions on their face appear to cloud personal jurisdiction issues, application of traditional personal jurisdiction tests has usually been successful in deciding personal jurisdiction issues in Internet cases. ${ }^{113}$ As seen in these cases, there is no clear and consistent rule of application for personal jurisdiction issues involving the Internet.

\section{iii. Application under the Central Hudson Test}

While it is difficult to know how exactly a court would decide the legal and nonmisleading prong of the Central Hudson test, there is a distinct trend of allowing cases to be prosecuted in a jurisdiction whenever possible. ${ }^{114}$ If the standard in Millennium Music is used, the commercial activity of the websites would be judged. ${ }^{115}$ This would produce

\footnotetext{
${ }^{110}$ Inset Sys., Inc. v. Instruction Set, Inc., 937 F.Supp. 161, 164-65 (D.Conn. 1996).

${ }_{111}^{11}$ See World-Wide Volkswagen Corp. v. Woodson, 444 U.S. 286 (1980).

${ }_{112}$ See S. Morantz Corp. v. Shine Ultrasonics, Inc., 79 F.Supp.2d 537, 539 (D. E.D. Pa. 1999).

${ }^{113}$ New York v. Lipsitz, 663 N.Y.S.2d. 468, 473 (N.Y. App. Div. 1997).

${ }^{114}$ See supra $\S \mathrm{V}-\mathrm{D}$-ii.

${ }^{115} \mathrm{Id}$.
} 
a subjective test that would require a court to judge the commercial activity of every website that facilitates online gambling. However, most casinos would be subject to jurisdiction because an online casinos' primary activity, soliciting bets from consumers, is entirely commercial in nature. Under the Millennium Music standard it is probable that most online casinos would be subject to personal jurisdiction

Other standards have noted that if the website is able to be viewed in a state, then the website is soliciting business in that state and is subject to personal jurisdiction in that state. ${ }^{116}$ Under this analysis, online casinos would be subject to personal jurisdiction in every state or country because the casinos would be accessible to website users all over the world. Some courts may find that this standard violates notions of substantial fair play and justice in situations where haling the casino into court would be overly burdensome. Under traditional personal jurisdiction analysis, online casinos would be subject to jurisdiction only in places where they have conducted business or specifically run advertisements. ${ }^{117}$ Again, substantial fair play and justice may play a role in certain cases. Online casinos are most likely subject to personal jurisdiction in any state no matter what mode personal jurisdiction analysis is used if substantial fair play and justice is not a problem.

As a result, online casinos might be found to be illegal and subject to U.S. jurisdiction which would make regulations against online casino advertising permissible even if other prongs of the Central Hudson test were not met. ${ }^{118}$ Personal jurisdiction standards created for the Internet include online casinos. If a court in a state where gambling is illegal wants to prosecute an online casino based in Antigua, they would be

\footnotetext{
${ }^{116}$ Lipsitz, 663 N.Y.S.2d. at 473.

${ }_{117}^{17}$ See supra § V-D-ii.

${ }^{118}$ See Bruce Keller, 108 YALE L.J. 1569, 1599-1603 (1999).
} 
able to hale the online casino into court and be able to prosecute the online casino if the court felt that jurisdiction did not violate notions of substantial fair play and justice.

Online casino advertising would be illegal in many states because if online gambling is illegal then the legal and non-misleading prong of the Central Hudson test could not be satisfied. These results leave a confused situation for the legality of online casino advertising that leads to three potential results assuming the U.S. District Court's February 2005 decision has not already settled the legality of online casino advertising.

VI. The District Court's Ruling February 2005 Decision

On February 17, 2005, the United States District Court for the Middle District of Louisiana upheld the federal government's Motion to Dismiss holding that Casinocity.com lacked standing to bring an action for a declaratory judgment. ${ }^{119}$ The District Court reasoned that because Casinocity.com did not receive a letter from the Department of Justice, like other broadcasters received, advising Casinocity.com that their behavior might be illegal and because Casinocity.com had not been served a subpoena, Casinocity.com was not in danger of being sued by the Department of Justice. As a result, the court said that Casinocity.com did not need a declaratory judgment to protect itself from the government. ${ }^{120}$ What is potentially more troubling for Casinocity.com is that the court elaborated further saying that even if Casinocity.com had standing, the government's regulation would be permissible because online casinos are illegal. $^{121}$

\footnotetext{
${ }^{119}$ See Spencer E. Ante, Casino City is Upping it Bet, Business WeEK, Feb. 18, 2005, available at http://www.businessweek.com/technology/content/feb2005/tc20050218_1299_tc024.htm (last visited Sept. $16,2005)$.

${ }^{120} \mathrm{Id}$.

${ }^{121} I d$.
} 
Casinocity.com has filed an appeal with the Court of Appeals for the Fifth Circuit hoping to overturn the District Court's adverse ruling. In their appeal, Casinocity.com is arguing that they have standing to seek a declaratory judgment while also seeking First Amendment protection for its advertising. ${ }^{122}$ The District Court dismissed Casinocity.com's First Amendment argument without much analysis and it is believed that the legality of online casino advertising will be more critically analyzed on appeal. ${ }^{123}$ In particular, analysts believe that the court misapplied the Wire Act and also ignored the jurisdictional issues discussed previously. ${ }^{124}$ So, while the initial ruling in Casinocity.com's case is adverse to Casinocity.com, the legality of online casino advertising is still an unsettled matter and the issues discussed in this paper are still relevant to the resolution of the problem.

\section{Likely Results}

The legality of online casino advertising has three probable results. First, online casino advertising could be found to be legal throughout the United States. Second, online casino advertising could be found to be illegal throughout the United States. Third, online casino advertising could be found to be legal in states where gambling is legal and illegal in states where gambling is illegal. Regardless, the regulation of online casino advertising will be difficult because of universal access of websites to all Internet users.

Problems exist with an outright ban on online casino advertising or a universal acceptance of online casino advertising. States have a vested interest in protecting the

\footnotetext{
${ }^{122} I d$.

${ }^{123} \mathrm{Id}$.

${ }^{124} \mathrm{Id}$.
} 
rights of citizens in their states. ${ }^{125}$ Therefore, an outright ban on online casino advertising does not recognize the rights of those in states that allow gambling while a universal acceptance of online casino advertising does not protect the right of a state to protect its citizens from things the state believes to be illegal. ${ }^{126}$ Greater New Orleans Broadcasting Association endorsed this thinking noting that a state that permits gambling does not have a sufficient interest in prohibiting casino advertising, but also saying that states that forbid gambling have a substantial interest in protecting their citizens from casino advertising. ${ }^{127}$ However, the advantage to no ban or an outright ban on advertising is that it avoids the problems of different standards throughout the country. If the third approach is taken, and advertising is legal in states that permit gambling and illegal in states that forbid gambling, it will be extremely difficult to enforce a fractured prohibition.

The third approach that allows advertising in states where gambling is legal seems to be the approach that is most consistent with previous decisions on casino advertising. ${ }^{128}$ As has been discussed before, these decisions are often difficult to apply in an online context. There is no easy way to enforce a ban on online casino advertising in a select number of states. ${ }^{129}$ This is primarily because there is no effective way to block online advertisements from reaching an Internet user. A universal ban on advertising would allow government officials to target anybody who advertised online casinos to United States citizens, but a mixed result would be difficult to enforce. For

\footnotetext{
${ }^{125}$ See Greater New Orleans Broad. Ass'n, 527 U.S. at 188; Valley Broad. Co., 107 F.3d at 1334.

${ }^{126}$ See supra $\S$ III-A.

${ }^{127} \mathrm{Id}$.

${ }^{128}$ See supra § III-a.

${ }^{129}$ See Rick Alm, Let's Legalize Cyber Gambling So We Can Regulate It, KANSAS City STAR, Nov. 23, 2004, available at http://www.kansascity.com/mld/kansascity/business/10249732.htm (last visited Jan. 29, 2005) (advocates legalizing casino gambling to assist in government regulation).
} 
example, an advertiser could not reasonably be held responsible to make sure that those in Nevada see the advertisement, while those in Delaware do not. The result of a mixed legality rule seems to be a greater burden than it is worth. However, an outright ban or acceptance of advertising contradicts current court decisions on gambling advertisements.

VIII. Conclusion

Though all three approaches to this issue have serous pitfalls, the most logical solution is to allow online casino advertising throughout the United States. As has been noted, a mixed ban would not be easily enforced and would not be an effective ban for those states that prohibit gambling. An outright ban of casino advertising would infringe on the rights of those who have the right to gamble within their jurisdiction. Further, a universal ban could not shut down online casinos that would still be able to operate within their countries of establishment and would likely still be accessible to those in the United States. Those who still wanted to use online casinos would probably find and access online casinos even if all advertising were banned in the United States. So, the most logical application is to permit online casino advertising in the United States.

The fact remains that the Internet has eliminated traditional notions of boundaries, and more specific to the legal world, jurisdictional boundaries. ${ }^{130}$ Online casino gambling is an activity that is nearly impossible to effectively regulate because online gambling is a borderless transaction. ${ }^{131}$ For example, if the Bellgaio, a popular Las Vegas casino, opened a casino in a state that forbid gambling, the government of that state could go to the casino and close it. However, an online casino usually reaches across the borders of several countries. If an online casino is based in Bermuda and

\footnotetext{
${ }^{130}$ See Jack Goldsmith, 5 IND. J. GLOBAL LEGAL STUD. 475 (1998).

${ }^{131}$ See Laura Bak-Boychuk, 6 Sw. J OF L. \& TRADE AM. 363, 383 (1999).
} 
solicits business globally through its website, how would a government outside Bermuda regulate this online casino? The government could sanction those transactions that reach the United States, but it would be powerless to shutdown the virtual casino located in Bermuda and would also probably be powerless to prosecute every transaction that involved a United States citizen. So, forbidding online casino advertising is not a practical way of preventing online gambling.

Further, there has been a shift in the United States towards greater acceptance of gambling in general. Pennsylvania is in the process of issuing slot machine licenses to certain establishments in the state. ${ }^{132}$ Also, poker games like Texas Hold 'Em have gained popularity among amateur players and have also received strong ratings on various cable networks. ${ }^{133}$ Federal legislation has become more permissive as tribal casinos have been legalized, and various exceptions for lotteries, charitable games and other similar gaming schemes have been permitted. While allowing online casino advertising does not satisfy the interests of all involved parties it offers the most logical and enforceable solution to the problem. The increased acceptance of gambling throughout the country seems to make this decision even more practical than an outright ban or a mixed ban between the states.

Gambling has been a governmental concern for years. The Internet has given great complexity to the regulation of online gambling and more specifically online casino advertising. Unlike traditional gambling advertising which can be regulated state-bystate, online casino advertising, like online gambling, is a global issue complicated by the

\footnotetext{
132 See John Richards, Weighing the Pros, Cons, Washington ObSERVER RePOrter, Nov. 132004 , at A1.

${ }^{133}$ See Elizabeth St. John, Texas Hold Em Gains Popularity, THE ARKANSAS TrAVELER, Oct. 4, 2004, available at http://www.thetraveleronline.com/main.cfm/include/detail/storyid/740074.html (last visited Jan. 29, 2005).
} 
borderless nature of the Internet. The most logical result is to permit online casino advertising throughout the United States. Regardless, the courts will have many difficult decisions to make in deciding the legality of online casino advertising in terms of applying current case law to an online issue, applying the Wire Act and analyzing jurisdiction issues. After deciding all of these complex issues, the court will have to reach a reasonable decision, even though all of the possible results have potentially negative effects, like allowing unregulated online gambling to continue or blocking access to certain websites to all citizens. It is very likely that the issue of online casino advertising will be appealed through the courts several times before a final decision on its legality is determined. 